\title{
The assessment of the amount of fat in the human body from measurements of skinfold thickness
}

\author{
By J. V. G. A. DURNIN AND M. M. RAHAMAN \\ Institute of Physiology, The University, Glasgow, W2 \\ (Received 29 December I966-Accepted 18 fanuary 1967)
}

\footnotetext{
r. Skinfold thickness and body density were measured on ro5 young adult men and women and 86 adolescent boys and girls.

2. The correlation coefficients between the skinfold thicknesses, either single or multiple, and density were in the region of -0.80 .

3. Regression equations were calculated to predict body fat from skinfolds with an error of about $\pm 3.5 \%$.

4. A table gives the percentage of the body-weight as fat from the measurement of skinfold thickness.
}

A simple method of assessing quantitatively the fat content of the human body, which could be used not only in laboratories and in hospital, but in field studies and in general medical practice, would be invaluable. Methods in use at present, based on measurements of body density, body water or body potassium, can be applied only in the laboratory and usually to small numbers of subjects.

Several previous papers have suggested relationships between one of the accepted methods of determining body fat and a simpler technique which could be widely applied. As early as 1921, Matiegka (1921) formulated an equation for calculating body fat from measurements of surface area and six skinfold thicknesses. Brožek \& Keys (I95I) were the first to use the relationship between skinfold thickness and body density for assessing fat content. The skinfolds chosen were not ideal and their formula has not been widely used. Pascale, Grossman, Sloane \& Frankel (1956) in the USA produced an equation, and Pařizková (196r $a$ ) in Czechoslovakia a nomogram, for predicting fat content from skinfold thicknesses. Steinkamp, Cohen, Gaffey, McKay, Bron, Siri, Sargent \& Isaacs (1965) gave predictive equations based on measurements of body circumferences and skinfold thicknesses on 167 subjects in California. The only comparable attempt on a British population, to our knowledge, is a study on twenty-four hospital patients, measurements being made of total body water and skinfold thickness (Fletcher, 1962).

Information about a wide range of body types in population groups in Britain is required. The present paper describes a study on 105 young adults and 86 adolescents. By means of results from measurements by anthropometry including skinfold thicknesses and body density, an attempt has been made to formulate simple equations for the prediction of the quantity of fat in the body. The subjects were of varying body build - thin, intermediate, plump, but very few were obese. 
EXPERIMENTAL

\section{Anthropometry}

The height, standing and sitting, the bi-acromial and bi-iliac diameters, and the girth of the upper arm, upper thigh and calf were measured on all subjects. Details of the techniques used, other than for the skinfolds, are given elsewhere (Rahaman \& Durnin, to be published).

\section{Skinfold thickness}

All measurements were taken, with the subject seated on a stool, on the right side of the body. The sites selected were as follows. (I) Biceps: over the mid-point of the muscle belly with the arm resting supinated on the subject's thigh. (2) Triceps: over the mid-point of the muscle belly, mid-way between the olecranon and the tip of the acromion, with the upper arm hanging vertically (Edwards, Hammond, Healy, Tanner \& Whitehouse, 1955). (3) Subscapular: just below the tip of the inferior angle of the scapula, at an angle of about $45^{\circ}$ to the vertical. (4) Suprailiac: just above the iliac crest in the mid-axillary line. At these four sites, the skinfold was pinched up firmly between the thumb and forefinger and pulled away slightly from the underlying tissues before applying the calipers for the measurement.

The instrument used was the Harpenden skinfold calipers (British Indicators Ltd, St Albans, Herts.), which exert a constant pressure at varying openings of the jaws. The width of the opening is read off on a scale incorporated in the apparatus. This instrument, however, is by no means ideal and an improved type is now available which is smaller and easier to use (Barr and Stroud, Glasgow).

\section{Body density}

Behnke and his colleagues (Behnke, Feen \& Welharn, 1942) were the first to suggest that the human body consists of a 'lean body mass' of fixed density (about $I \cdot I 0$ ) and a variable amount of fat which could be quantitatively assessed by measuring density. The experimental evidence for this deduction has been well examined by von Döbeln (1956). The measurement of density was made by weighing the subject in air and under water in a large tank with a correction being made for the residual air in the lungs. The subject expelled as much air from his lungs as possible before immersion and, as soon as the weight had been recorded, a measurement was made of the residual volume by the three-breath, nitrogen dilution technique (Rahn, Fenn \& Otis, I949). The $\mathrm{O}_{2}$, $\mathrm{CO}_{2}$ and $\mathrm{N}_{2}$ in the bag were measured in a Lloyd-Haldane apparatus. The whole procedure was repeated twice more, each time after an interval of a few minutes. The mean of the three calculated results for density was taken as the final value for the subject. The replicability of this technique has been tested by Durnin \& Taylor (1960). In another study on three subjects in the present series, where many separate measurements of density were made during a period of I year, the standard deviation was $\pm 0.0008 \mathrm{~g} / \mathrm{ml}$.

Before the measurements, each subject was accustomed to the procedures by several 
trial runs. However, in general, only people who felt reasonably confident in waterusually swimmers-were suitable subjects.

Calculations of the body fat were based on the equation given by Siri (1956):

$$
\text { Fat }(\%)=[(4.95 / \text { density })-4.5] \times 100 .
$$

Similar results are obtained by the use of other equations, such as that of Brožek, Grande, Anderson \& Keys (1963).

\section{Subjects}

Table I shows the age, height and weight of the subjects. There were few fat subjects (see Tables 3 and 4), since considerable difficulty was experienced both in finding such people and, once found, in persuading them to act as subjects.

The results were analysed by means of a KDF 9 Computer. Group correlation matrices of thirty-six variables, anthropometric and density, both measured and derived, were obtained. Simple regression analyses, using body density as the dependent variable and the log value of the sum of the four skinfolds as the independent one, were also carried out.

\section{RESULTS}

The results for the four groups, men, women, boys and girls, have been analysed separately. This separation was made because it is known that men differ from women in the amount of subcutaneous fat and it is at least possible that children and adolescents are not, in this respect, exactly similar to adults. Table 2 shows the values for the sum of the four skinfold thicknesses, for the density of the body, and for the percentage of fat as derived from the density. These results are divided in Tables 3 and 4 to show the varying picture of the different subgroups as they were initially divided by clinical assessment. Although the means for the subgroups differ considerably, the overlap in the ranges demonstrates the difficulty of a clinical or subjective assessment of degree of fatness and thinness. Particularly in the group of thin women, many subjects were found to have much more fat than expected.

The relationships were calculated between the density and the skinfold measurements, singly and in every possible combination. The correlation coefficients for total skinfold thickness and body density in young adult men and women were -0.835 and -0.778 respectively. In boys and girls the values were -0.760 and -0.778 respectively; all four correlation coefficients were significant $(P<0 \cdot 00 \mathrm{I})$. These were the highest coefficients with the single exception of the value for biceps in boys $(-0.8 \mathrm{I} 4)$. Of the remaining fifty-six coefficients only seven were below -0.700 . In every instance the value for $r$ was significant at the $0.00 \mathrm{r}$ level.

None of the anthropometric measurements made on all the subjects gave as high correlations as skinfolds with density; attempts to increase the degree of correlation, by combining several anthropometric measurements-such as adding some circumferences (the arm or the thigh) to the skinfolds-in the form of multiple regression analyses, made little difference to the values for $r$. Thus only skinfolds were used in the prediction of density. 

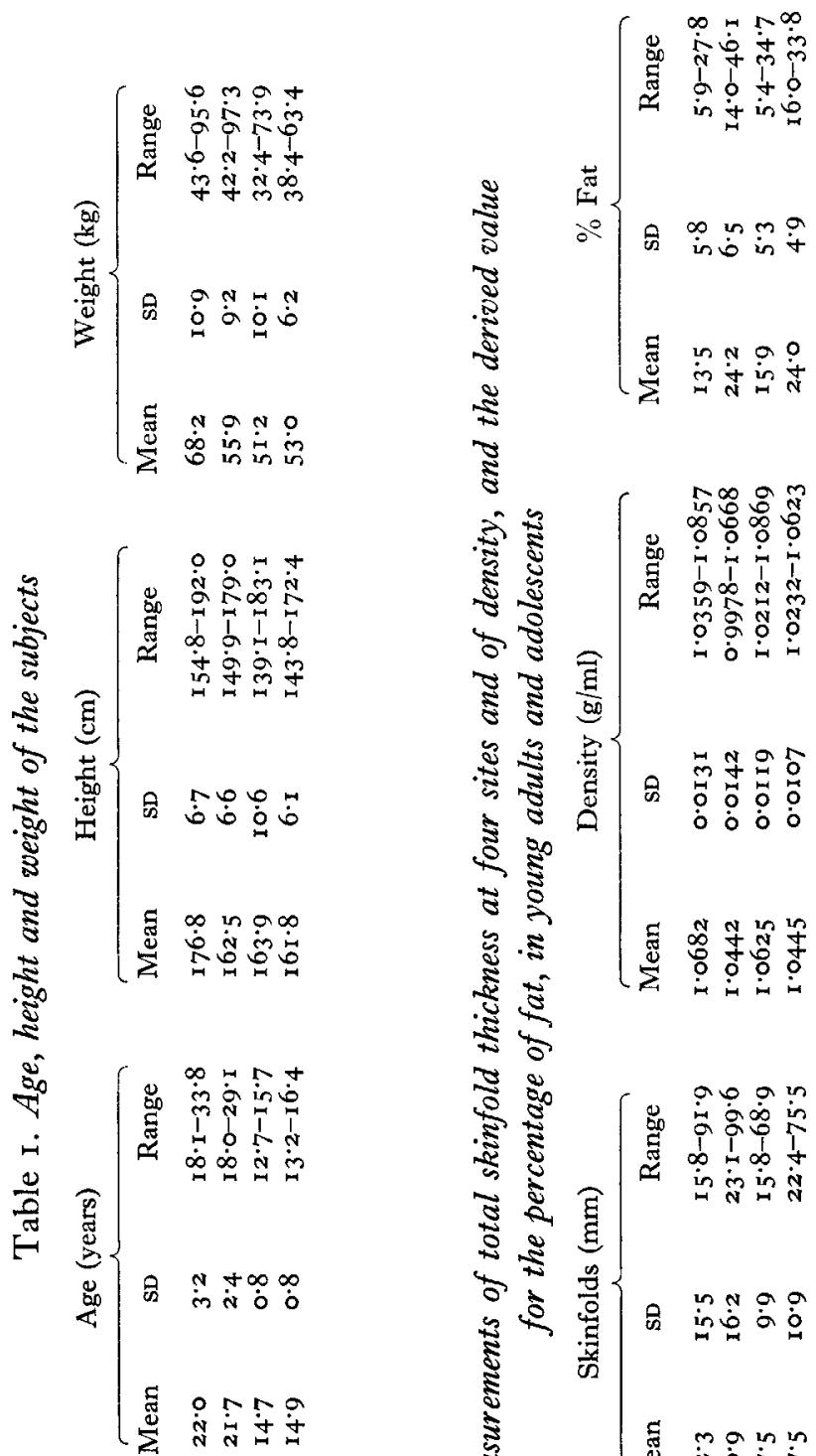

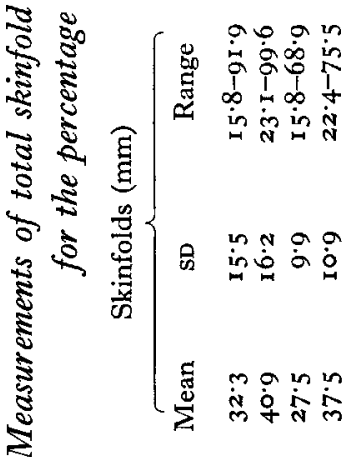

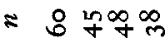

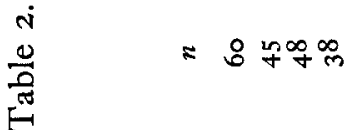

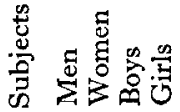

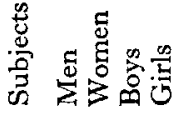


Table 3. Measurements of total skinfold thickness at four sites and of density in young adults, subdivided for body build assessed subjectively by appearance

\begin{tabular}{|c|c|c|c|c|c|}
\hline \multirow[b]{2}{*}{ Body build } & & \multicolumn{2}{|c|}{ Men } & \multicolumn{2}{|c|}{ Women } \\
\hline & & Skinfold (mm) & Density & Skinfold (mm) & Density \\
\hline Thin & $\begin{array}{l}\text { Mean } \\
\text { SD } \\
\text { Range } \\
n\end{array}$ & $\begin{array}{c}24 \cdot 0 \\
7 \cdot 1 \\
15 \cdot 8-45 \cdot 8 \\
32\end{array}$ & $\begin{array}{c}I \cdot 0747 \\
0.0092 \\
I \cdot 0528-I \cdot 0857\end{array}$ & $\begin{array}{c}3 I \cdot 2 \\
6 \cdot 3 \\
23 \cdot I-43 \cdot 4 \\
16\end{array}$ & $\begin{array}{c}\mathbf{I} \cdot 0547 \\
0.0073 \\
\mathbf{I} \cdot 0407-\mathbf{I} \cdot 0668\end{array}$ \\
\hline Intermediate & $\begin{array}{l}\text { Mean } \\
\text { SD } \\
\text { Range } \\
n\end{array}$ & $\begin{array}{l}35 \cdot 7 \\
15 \cdot 1 \\
21 \cdot 0-61 \cdot 3 \\
20\end{array}$ & $\begin{array}{c}\mathrm{I} \cdot 0663 \\
0.0197 \\
\mathrm{I} \cdot 044 \mathrm{I}-\mathrm{I} \cdot 08 \mathrm{ro}\end{array}$ & $\begin{array}{c}39 \cdot 9 \\
10.0 \\
28 \cdot 4-63 \cdot 4 \\
22\end{array}$ & $\begin{array}{c}I \cdot 0442 \\
0.0082 \\
I \cdot 0323-1 \cdot 0601\end{array}$ \\
\hline $\begin{array}{l}\text { Plump and } \\
\text { obese }\end{array}$ & $\begin{array}{l}\text { Mean } \\
\text { SD } \\
\text { Range } \\
n\end{array}$ & $\begin{array}{c}57 \cdot 2 \\
21 \cdot 4 \\
35 \cdot 7-9 x \cdot 9 \\
8\end{array}$ & $\begin{array}{c}I .0458 \\
0.0104 \\
I \cdot 0359-I \cdot 0649\end{array}$ & $\begin{array}{c}66 \cdot 0 \\
22 \cdot 7 \\
41 \cdot 2-99 \cdot 6 \\
7\end{array}$ & $\begin{array}{c}1.0198 \\
0.0122 \\
0.9978-1.0329\end{array}$ \\
\hline
\end{tabular}

Table 4. Measurements of total skinfold thicknesss at four sites and of density in adolescents, subdivided for body build assessed subjectively by appearance

\begin{tabular}{|c|c|c|c|c|c|}
\hline \multirow[b]{2}{*}{ Body build } & & \multicolumn{2}{|c|}{ Boys } & \multicolumn{2}{|c|}{ Girls } \\
\hline & & Skinfold (mm) & Density & Skinfold (mm) & Density \\
\hline Thin & $\begin{array}{l}\text { Mean } \\
\text { SD } \\
\text { Range } \\
n\end{array}$ & $\begin{array}{c}22 \cdot 4 \\
5 \cdot 3 \\
\times 5 \cdot 8-39 \cdot 9 \\
25\end{array}$ & $\begin{array}{c}x \cdot 0689 \\
0.0089 \\
\text { I.05 } 12-r \cdot 0869\end{array}$ & $\begin{array}{c}33 \cdot 3 \\
9.5 \\
22 \cdot 4-50 \cdot 0 \\
10\end{array}$ & $\begin{array}{c}I \cdot 0506 \\
0.0082 \\
I \cdot 0383-I \cdot 0623\end{array}$ \\
\hline Intermediate & $\begin{array}{l}\text { Mean } \\
\text { SD } \\
\text { Range } \\
n\end{array}$ & $\begin{array}{c}29 \cdot 7 \\
7 \cdot 6 \\
17 \cdot 5-47 \cdot 9 \\
18\end{array}$ & $\begin{array}{c}I \cdot 05^{63} \\
0.0094 \\
I \cdot 0374-I \cdot 0695\end{array}$ & $\begin{array}{c}36 \cdot 2 \\
8 \cdot 8 \\
23 \cdot 3-53 \cdot 5 \\
21\end{array}$ & $\begin{array}{c}1 \cdot 045 I \\
0.0089 \\
I \cdot 0348-1 \cdot 0627\end{array}$ \\
\hline $\begin{array}{l}\text { Plump and } \\
\text { obese }\end{array}$ & $\begin{array}{l}\text { Mean } \\
\text { SD } \\
\text { Range } \\
n\end{array}$ & $\begin{array}{c}43 \cdot 2 \\
13 \cdot 2 \\
32 \cdot 3-68 \cdot 9 \\
6\end{array}$ & $\begin{array}{c}1.0486 \\
0.0142 \\
1 \cdot 0212-1 \cdot 0622\end{array}$ & $\begin{array}{c}49 \cdot 0 \\
13 \cdot 6 \\
35 \cdot 2-75 \cdot 5 \\
7\end{array}$ & $\begin{array}{c}I \cdot 0340 \\
0.0114 \\
I \cdot 0232-I \cdot 0504\end{array}$ \\
\hline
\end{tabular}

\section{DISCUSSION}

The thickness of the four skinfolds is of the same order for men and boys and also for the women and girls (Table 2). However, although the men have a slightly higher mean skinfold thickness than the boys, which might indicate a greater quantity of fat, the mean body density is higher and therefore the fat content of the whole body is apparently less. This difference might reflect some changes in the nature of the fat-free mass, and thus in the validity of the calculation of body fat from density. In the theoretical derivation of body fat from measurements of body density, there are no special equations available for use with children or adolescents. This is because of the lack of knowledge on body composition in children, particularly in regard to possible differences in the composition of muscle, or of its mass relative to the rest of the fatfree mass, or in the composition of the skeleton.

Because of this uncertainty, some previous workers, for example, Pařízková ( $196 \mathrm{I} b$ ) 
and Novak (1963) have expressed their results in density units and have not used them to derive body fat content. Although it is possible that children differ from adults in the density of the fat-free mass, there is some indirect evidence to suggest that, at the age of our subjects ( $13^{-15}$ years), the body composition is similar to that of adults (Hunt \& Heald, I963; Vener, I933).

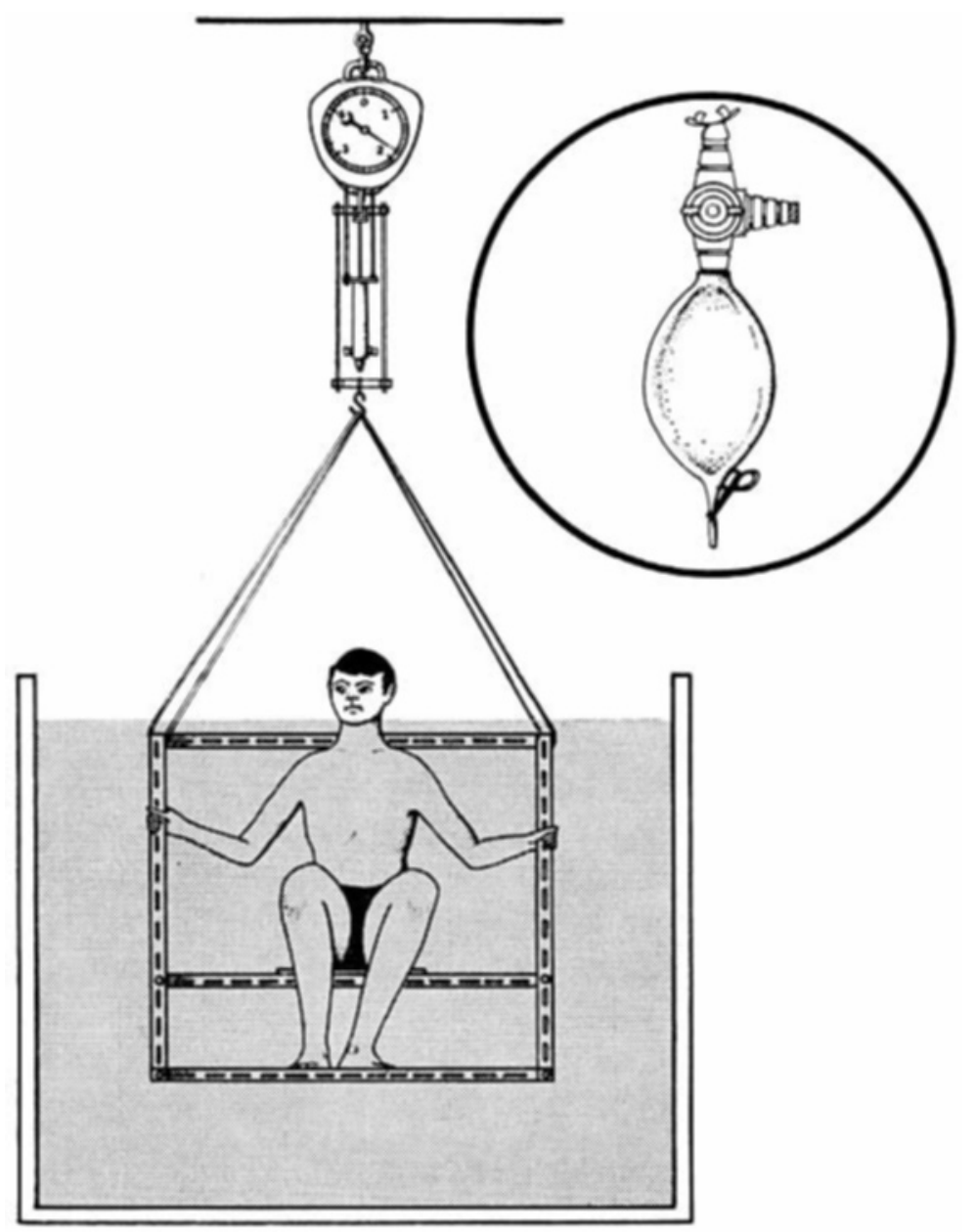

Fig. 1. Diagrammatic presentation of the underwater weighing apparatus. The inset shows the apparatus for the measurement of residual volume.

An alternative explanation of the difference between adolescent and young adult men might be that the distribution of the fat in the body differs. A greater proportion of the fat in adults may be in the subcutaneous tissues. This is supported by the fact that the correlations between skinfold and density were different for boys and young men but the same for the girls and young women. The maturity of the girls almost certainly resembled the adult state and perhaps this was not so true for the boys.

Several equations have already been suggested for the prediction of body fat from 
simple anthropometric measurements; few of them have been tested by independent observers. Young \& Blondin (1962) and Damon \& Goldman (1964) have attempted this test but, so far, not conclusively. Also, populations differ and results obtained on American adults may not be pertinent to British groups.

Table 5. Regression equations for the prediction of body density $(Y)$ from the log of the sum of skinfold thicknesses at all four sites in $\mathrm{mm}(X)$

\begin{tabular}{llc} 
Subjects & \multicolumn{1}{c}{ Equation } & SE of estimate \\
Men & $Y=I \cdot I 610-0.0632 X$ & \pm 0.0069 \\
Women & $Y=I \cdot I 581-0.0720 X$ & \pm 0.0096 \\
Boys & $Y=I \cdot 1533-0.0643 X$ & \pm 0.0083 \\
Girls & $Y=I \cdot I 369-0.0598 X$ & \pm 0.0081
\end{tabular}

For the purpose of a useful practical prediction, which can be utilized by anyone competent in measuring skinfold thickness, regression equations have been calculated and are given in Table 5 . The calculation is very simple, and entails a conversion of the total skinfold, measured in $\mathrm{mm}$, into the logarithmic value. For example, if the total thickness at four sites in a man is $35.6 \mathrm{~mm}$, the logarithmic value of this is $\mathrm{I} \cdot 55^{\mathrm{I}} 5$. If the equation for young men is substituted,

$$
\begin{aligned}
Y & =\mathrm{I} \cdot \mathrm{I} 6 \mathrm{I0}-0.0632(\mathrm{I} \cdot 55 \mathrm{I} 5) \\
& =\mathrm{I} \cdot \mathrm{I} 6 \mathrm{I0}-0.098 \mathrm{I}, \\
\therefore Y & =\mathrm{I} \cdot 0629 .
\end{aligned}
$$

With this value for the density in the Siri equation (p. 683), it can be calculated that the subject has $16 \%$ of the body-weight as fat.

Although it is possible to make predictions from measurements of skinfold thickness at only one or two sites, it is recommended that all four skinfolds should be measured. The reasons are that four sites are more representative of the distribution of fat than a smaller number, and also a single small error in measurement becomes less important. For simple practical use, in order to avoid obtaining log values and making the appropriate calculations, Table 6 gives a direct transformation of skinfold thickness using these four sites in absolute values as they would be obtained by measurement, and the equivalent percentage of fat in the body. As there are differences between age-groups and between the sexes, it is essential to use different equations for men and women, boys and girls.

For the calculation of the regression equations, logarithmic, instead of absolute values, were used. This is preferable since the relationship of skinfolds to density is curvilinear and not rectilinear, and skinfold values have a skewed distribution in the body (the suprailiac or subscapular may be four times greater than the biceps) (Edwards et al. 1955; Tanner, 1962; Tanner \& Whitehouse, 1962).

Table 5 also shows the extent of the standard error, which, when converted into percentage of fat by means of Siri's equation, is between \pm 3 and $3.5 \%$. For all practical purposes, and considering the lack of certainty in the derivation of the basic calculation, this error is within acceptable limits. In most instances it is sufficient to know whether someone has, for example 10\%, $20 \%$ or $30 \%$ of their body-weight as fat. 
There are certain theoretical limitations to the use of Table 6 which have to be discussed. The exact relationship between density and fat content in adolescents is not known. It is even possible that women may have a different density of the fat-free mass than men. But until more information becomes available, the assumptions made

Table 6. Percentages of fat corresponding to the total value of skinfolds at four sites (biceps, triceps, subscapular and suprailiac)

\begin{tabular}{|c|c|c|c|c|}
\hline \multirow{2}{*}{$\begin{array}{l}\text { Total } \\
\text { skinfold } \\
\text { (mm) }\end{array}$} & \multicolumn{4}{|c|}{ Fat ( $\%$ body-weight) } \\
\hline & Men & Women & Boys & Girls \\
\hline 15 & 5.5 & - & 9.0 & $12 \cdot 5$ \\
\hline 20 & $9 \cdot 0$ & 15.5 & $12 \cdot 5$ & 16.0 \\
\hline 25 & II' 5 & 18.5 & 15.5 & 19.0 \\
\hline 30 & 13.5 & $21 \cdot 0$ & $17 \cdot 5$ & $2 I \cdot 5$ \\
\hline 35 & 15.5 & $23 \cdot 0$ & $19 \cdot 5$ & 23.5 \\
\hline 40 & $17^{\circ} 0$ & 24.5 & $2 \mathrm{I} \cdot 5$ & 25.0 \\
\hline 45 & $18 \cdot 5$ & 26.0 & 23.0 & 27.0 \\
\hline 50 & 20.0 & 27.5 & 24.0 & $28 \cdot 5$ \\
\hline 55 & $2 I \cdot 0$ & 29.0 & 25.5 & 29.5 \\
\hline 60 & $22 \cdot 0$ & 30.0 & $26 \cdot 5$ & 30.5 \\
\hline 65 & $23 \cdot 0$ & $3 I \cdot 0$ & 27.5 & 32.0 \\
\hline 70 & 24.0 & $32 \cdot 5$ & $28 \cdot 5$ & 33.0 \\
\hline 75 & 25.0 & 33.5 & $29 \cdot 5$ & 34.0 \\
\hline 80 & 26.0 & 34.0 & - & - \\
\hline 85 & $26 \cdot 5$ & $35^{\circ} \circ$ & 一 & - \\
\hline 90 & $27 \cdot 5$ & $36 \cdot 0$ & - & - \\
\hline 95 & 28.0 & $36 \cdot 5$ & - & - \\
\hline
\end{tabular}

in this paper appear reasonable. It should be pointed out that one group has not been adequately studied. It was extremely difficult to find really thin women. Women who appeared superficially very thin usually turned out to have more than $20 \%$ of their body-weight as fat. Two of the women were athletes of national standard and in training. Their body fat was around $15 \%$. It may well be that the basic formulas are incorrect in this instance, since it is difficult for the authors to believe that the values obtained for the fat content in these two subjects were not erroneously high.

Middle-aged and elderly people may also differ from the young adult state in the relation between skinfolds and total fat. This group is at present being studied.

With the use of the recommended skinfold calipers and the expenditure of a minimum of time and trouble, it should now be possible in hospital, in general practice, and in laboratory work, to obtain an objective assessment of the amount of fat in a person's body. The advantages of such an estimate are considerable and should allow a much more satisfactory interpretation and follow-up of many clinical conditions.

We are grateful to Messrs T. McKim and S. Whyte and to Miss M. Friskey for technical assistance. Miss J. Wheatcroft was responsible for the computer analyses. The work described is part of a project financed through Grant AM 05104 from the US Public Health Service. 


\section{REFERENCES}

Behnke, A. R., Feen, B. G. \& Welham, W. C. (r942). F. Am. med. Ass. Ir8, 495.

Brožek, J., Grande, F., Anderson, J. T. \& Keys, A. (1963). Ann. N.Y. Acad. Sci. 110, 113.

Brožek, J. \& Keys, A. (195 I). Br. F. Nutr. 5, 194.

Damon, A. \& Goldman, R. F. (1964). Hum. Biol. 36, 32.

Durnin, J. V. G. A. \& Taylor, A. (1960). F. appl. Physiol. 15, 142.

Edwards, D. A. W., Hammond, W. H., Healy, M. J. R., Tanner, J. M. \& Whitehouse, R. H. (1955). Br. . Nutr. 9, 133 .

Fletcher, R. F. (1962). Clin. Sci. 22, 333.

Hunt, E. E. Jr \& Heald, F. P. (1963). Ann. N. Y. Acad. Sci, 110, 532.

Matiegka, J. (192 I). Am. J. Phys. Anthrop. 4, 223.

Novak, L. P. (1963). Ann. N.Y. Acad. Sci. Iro, 545.

Pař́zková, J. (ı 96 r a). Metabolism Io, 794.

Pařízková, J. (1961 b). F. appl. Physiol. 16, I73.

Pascale, L. R., Grossman, M. I., Sloane, H. S. \& Frankel, T. (1956). Hum. Biol. 28, 165.

Rahn, H., Fenn, W. O. \& Otis, A. B. (1949). J. appl. Physiol. 1, 725.

Siri, W. E. (1956). In Advances in Biological and Medical Physics. [J. H Lawrence and C. A. Tobias, editors.] London and New York: Academic Press Inc.

Steinkamp, R. C., Cohen, N. L., Gaffey, W. R., McKay, T., Bron, G., Siri, W. E., Sargent, T. W. \& Isaacs, E. (1965). F. chron. Dis. 18, 1291.

Tanner, J. M. (1962). In Growth at Adolescence, and ed., p. 241. Oxford: Blackwell Scientific Publications.

Tanner, J. M. \& Whitehouse, R. H. (I962). Br. med. F. i, 446.

Vener, Y. A. (1933). In White House Conference on Child Health and Protection; Growth and Development of the Child. Part 2. Anatomy and Physiology, p. 92, New York: Century.

von Döbeln, W. (1956). Acta. physiol. scand. 37, suppl. 126.

Young, C. M. \& Blondin, J. (1962). F. Am. diet. Ass. 41, 452. 